\title{
Technology Commercialization Cost Modeì and Component Case Study
}

\author{
Final Report
}

Work Performed Under Contract No.: DE-AC21-86MC25104

For

U.S. Department of Energy

Office of Fossil Energy

Morgantown Energy Technology Center

P.O. Box 880

Morgantown, West Virginia 26507-0880

By

BoozoAllen \& Hamilton Inc.

4330 East West Highway

Bethesda, Maryland 20814

and

Michael A. Cobb \& Co.

1688 Brookwood Drive

Akron, Ohio 44313

December 1991 


\section{ACKNOWLEDGMENTS}

The authors acknowledge the efforts of the Government and industry personnel who assisted in this study by providing valuable contributions towards the establishment of a Technology Commercialization Cost Model and Component Case applicable to the fuel cell community.

Special thanks are extended to Mr. Thomas George of the U.S. Department of Energy, Morgantown Energy Technology Center (DOE/METC) for his support and encouragement, and for providing us the opportunity to develop and demonstrate this model for the fuel cell industry.

We also thank those members of industry who dedicated significant time and energy (gratis) toward helping our team understand their willingness, as suppliers, to develop and provide raw material that meet the unique requirements of the fuel cell community. In particular, we thank:

PFIZER MINERALS

PIGMENTS \& METALS DIVISION

Dr. Robert Froberg

UCAR CARBON COMPANY INC.

Mr. Dave Page

INCO ALLOYS INTERNATIONAL, INC.

Dr. Thomas Lemke

Mr. H.D. Rice

J\&L SPECIALTY PRODUCTS CORP.

Mr. John C. Bruno

Mr. Philip J. Rouse
ARMCO RESEARCH \& TECHNOLOGY

Mr. William J. Schumacher

Dr. Farrell M. Kilbane

Mr. Alan Gibson

Mr. Richard F. Lyke

Dr. James N. Cordea

Dr. Jerry L. Arnold

This work was supported by the U.S. Department of Energy, Morgantown Energy Technology Center, Fuel Cell Branch under Contract Number DE-AC21-86MC25104. 


\section{TABLE OF CONTENTS}

TECHNOLOGY SELECTION METHODOLOGY - OVERVIEW

I. TECHNOLOGY DEVELOPMENT EVALUATION PROCESS

- Product Commercialization Framework

- Business Analysis Approach

II. A PRODUCT COST ESTIMATING APPROACH

- $\quad$ Estimating Próduction Cost

- Cost Estimating Approach Demonstration

III. MATERIAL INFRASTRUCTURE CASE STUDIES

- Graphite Separator Plates

- Nickel Clad Stainless Steel 


\section{INDEX OF EXHIBITS}

EXHIBIT

I-1 PRODUCT COMMERCIALIZATION FRAMEWORK

I-2 TECHNOLOGY DEVELOPMENT EVALUATION CRITERIA

I-3 FUEL CELL DEVELOPMENT TIME LINE

I-4 BUSINESS ANALYSIS APPROACH

II-1 COST SEGMENTATION BY MAJOR MANUFACTURING COST ELEMENT

II-2 COST SEGMENTATION BY MAJOR CELL STACK COMPONENT

II-3 PRODUCTION PLAN MAJOR DELIVERABLES
PAGE

II-6

II-6

II-7 
TECHNOLOGY SELECTION METHODOLOGY OVERVIEW 
Technology Selection Methodology ...

\section{OVERVIEW}

Fuel cells seem poised to emerge as a clean, efficient, and cost competitive source of fossil fuel based electric power and thermal energy. Environmental and market forces are combining to demand such power systems, and a variety of groups are rushing to meet this demand with large scale commercial fuel cell products. These will serve applications ranging from single buildings to utility baseload generation.

Fuel cells are based on a variety of technologies such as phosphoric acid electrolyte, molten carbonate electrolyte and solid oxide electrolyte. Each of these technologies has a unique set of advantages, disadvantages, costs and risks which will determine in which segment of the market it succeeds and in what time frame. Within each technology and market segment the various developers are evolving different product designs and manufacturing approaches. Ultimately, market forces will select the winners for each market segment. Sponsors of fuel cell technology development, however, need to determine the validity and the attractiveness of a technology to the market in terms of meeting requirements and providing value which exceeds the total cost of ownership.

Sponsors of fuel cell development, including the DOE, EPRI and GRI, have addressed this issue by requiring the developers to prepare projections of the future production cost of their fuel cells in commercial quantities. These projected costs, together with performance and life projections, provide a preliminary measure of the total value and cost of the product to the customer. Booz-Allen \& Hamilton Inc. and Michael A. Cobb \& Company have been retained in several assignments over the years to audit these cost projections. The audits have gone well beyond a simple review of the numbers. They have probed the underlying technical and financial assumptions, the sources of data on material and equipment costs, and explored issues such as the realistic manufacturing yields which can be expected in various processes.

Based on the experience gained from these audits, the DOE gave Booz.Allen and Michael A. Cobb \& Company the task to develop a criteria to be used in the execution of future fuel cell manufacturing cost studies. It was thought that such a criteria would make it easier to execute such studies in the future as well as to cause such studies to be more understandable and comparable.

Fuel cell manufacturing costs are dependent on both internal factors including the product technology and rianufacturing processes, and external factors including material markets and the capabilities of outside suppliers. The study therefore addressed both areas.

The internal cost factors were addressed by developing and testing a cost estimating approach which is applicable to fuel cells at various stages of the development and commercialization process. It was a particular objective to account for costs such as waste 
Technology Selection Methodology ...

disposal and environmental controls, and credits such as used stack salvage value. The first step was to review the fuel cell technology development and commercialization process, based on experience with the carbonate and phosphoric acid technologies. The second step was to develop a manufacturing (product) cost estimating approach adapted to the fuel cell field. Finally, the estimating approach was tested by using it to compare nickel clad versus copper clad separator plates for use in carbonate fuel cells. The methodology is equally applicable to analyzing the cost of alternate phosphoric acid components, or comparing cost elements between two technologies such as phosphoric acid and carbonate. Phosphoric acid was not used in the sample analysis since this could reveal proprietary data.

The external cost factors were addressed through case studies which explored the cost and availability of two key materials; clad material for carbonate separator plates and graphite sheets for phosphoric acid separator plates. The first step in these studies was to use a variety of sources including industry directories and contacts in the industry to identify potential suppliers. The second step was to establish a dialogue with the potential suppliers to brief them on the opportunity, review their capabilities to provide the materials to specification, and discuss their interest in working with the fuel cell industry. The dialogue included some phone calls, letters and face to face meetings. Finally, those suppliers with interest were put in touch with the appropriate developers and sponsors to pursue the opportunities. These studies are intended to be a model of the methodology required to identify the industrial infrastructure which can support fuel cell commercialization, and to start a cooperative process between suppliers and developers.

\section{SUMMARY OF FINDINGS}

The sample analysis of the use of copper clad stainless steel versus nickel clad stainless steel demonstrates how the estimating approach is used. It also demonstrates the need to include factors such as used product scrap value which are not normally included in product cost estimates. In this case the copper material has a lower first cost because copper is less expensive than nickel. Stainless steel scrap containing copper, however, has little value because the copper contaminates stainless steel melts. Stainless steel scrap, on the other hand, has high value because the nickel is a necessary ingredient in stainless steel melts. The result is that the nickel clad material has a lower cost over the life of the product. This issue of material scrap value is expected to be of importance in the commercial competition between phosphoric acid, carbonate and solid oxide technologies.

In case studies which were part of this task, we assessed the capability of the industrial infrastructure to provide wide nickel clad stainless steel for molten carbonate cells, and large area, thin impermeable graphite sheets for phosphoric acid separators in the grades and quantities required for commercial production. These were selected because of their high cost, and because they are critical to successful commercialization of these fuel 
Technology Selection Methodology ...

cell technologies. Further, the known suppliers were limited in number and located overseas. The outcome was that we identified domestic firms with applicable capabilities and interest who are not currently involved in fuel cell development. If, as seems likely, several of these firms become actively involved, the industrial base supporting commercialization will be expanded and the cost position of the developers will improve. Had the results been less favorable, we would have recommended an effort to develop the needed capabilities if it appeared practical and economically feasible to do so. If this did not seem feasible, then the developers would have to decide among options including design change or dependence on a limited infrastructure.

The case studies brought up an interesting point. They suggest that potential domestic suppliers of materials critical to fuel cell production are not learning about and acting on the opportunities early enough to participate the the industry development and gain a position as part of the established infrastructure. At best, they are in the discussion stages in the cases studied. In contrast, Japanese suppliers currently offer these materials in suitable sizes and specifications to both U.S. and foreign developers, and are seeing their materials built into key test and demonstration hardware. The domestic suppliers of these two materials are therefore in a catch-up position in an industry and technology the U.S pioneered and still leads. These test cases may be isolated incidents. If, however, it is a general condition, then special effort may have to be made to involve suppliers in the early stages of the fuel cell commercialization process.

In summary, it is clear that projected production cost estimates, including assessment of the capability of the industrial infrastructure to support the venture, are important tools for the developers and their sponsors. Such information is useful early in the new product development cycle to select technical options to pursue. It becomes even more vital as commercial introduction nears and large investments are considered.

In the following sections we will discuss the product development cycle in general terms from laboratory to commercialization, and describe a preliminary approach to evaluate the projected commercial manufacturing cost of fuel cell technologies. The separator plate case studies will be also be reviewed. The overall intent is to point up the usefulness of such techniques for guiding development and investment decisions, and assuring that the required infrastructure is in place for successful commercialization. 
Technology Development Evaluation Process ...

Numerous models have been established to characterize the development process of a technology as it evolves from a concept to a commercial product. All include the same basic elements of progressive, iterative development coupled with continuous technical and husiness evaluat ons. Presented below is a brief overview of a model that typifies this development process. This model establishes the framework within which a business analysis approach has been developed to determine the production cost of an emerging product technology. The business analysis approa:-h is structured to guide the sponsors of technology development in the evaluation of technologies to determine their probability of commercialization success.

\section{PRODUCT COMMERCIALIZATION FRAMEWORK}

A generalized model which illustrates the sequential development and evaluation of the technology commercialization process is shown in Exhibit I-1. As the technology evolves, frequently it is necessary to return to an earlier phase in the process in order to respond to changes in the market requirements, or to refine the technology. Technology refinements may include correcting problenis, or taking advantage of new developments in design, processes, or materials.

Key to this framework is the continuous business analysis of the technology to determine the viability of progressing to the next step based on the results of previous efforts. Each of the business analyses within the jroduct commercialization framework is similar and attempts to determine with increasing detail the potential value of the technology as it approaches commercialization.

The most common criteria used by management to assess the attractiveness of a technology development effort are shown in Exhibit I-2. As t e technology progresses through the commercialization process, the business analyses are conducted in greater detail as more information becomes available and the technology application is better defined. However, the primary reason for conducting the analyses in greater detail is that the magnitude of the investments and associated risks required for each subsequent step increases significantly as the technology progresses towards commercialization.

A business analysis of particular importance occurs just prior to commercialization. This analysis receives close scrutiny by management because of the large capital equipment investments to support full-scale production. This analysis is a major factor leading to a "Go" or "No Go" decision for commercialization. Frequently, several competing technologies are developed simultaneously for a specific application to the point of advanced development and testing (see Exhibit I-1), and then the most promising one or two technologies are selected for full commercialization. 
Technology Development Evaluation Process ...

\section{EXHIBIT I-1}

PRODUCT COMMERCIALIZATION FRAMEWORK

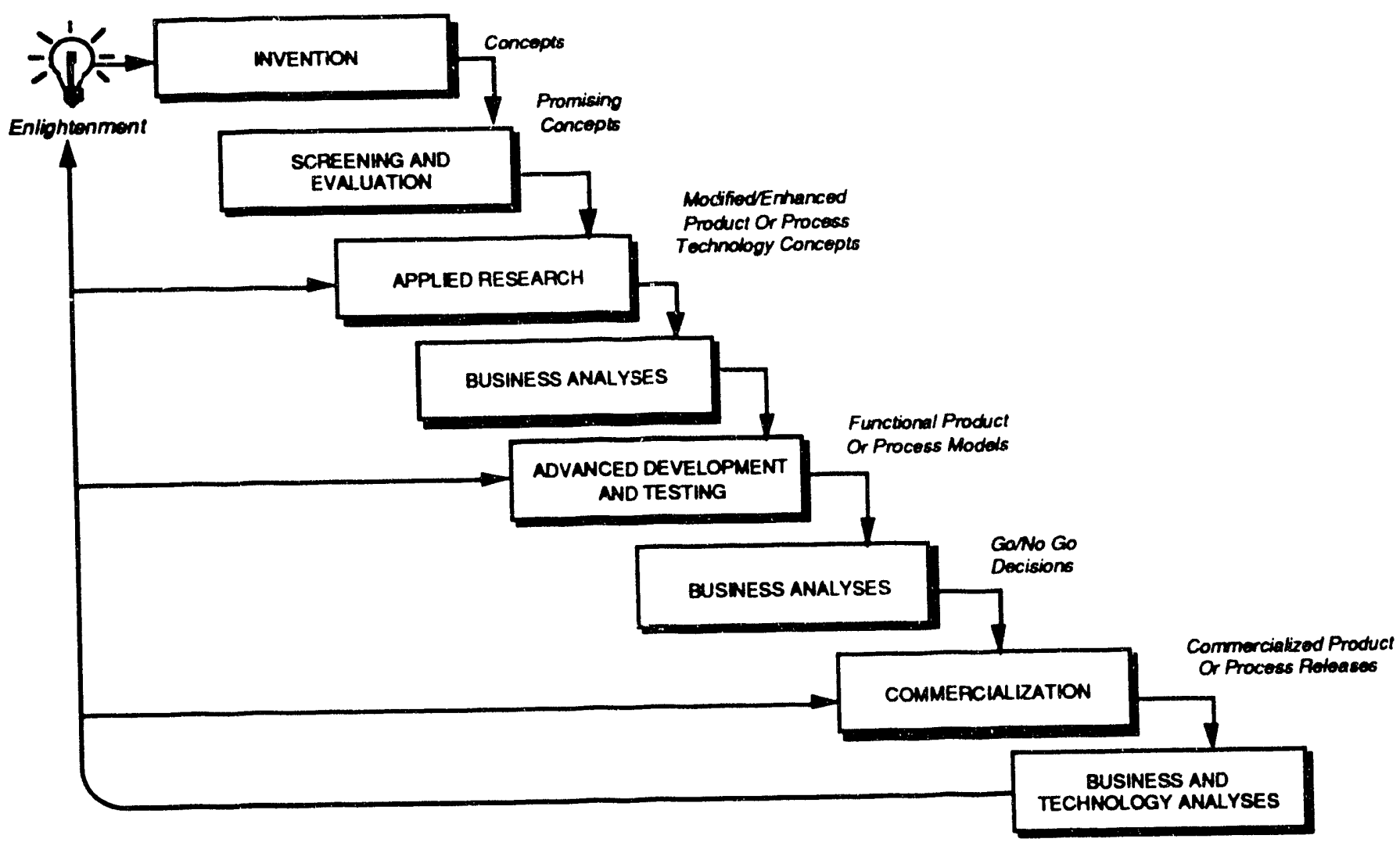

EXHIBIT I-2

TECHNOLOGY DEVELOPMENT EVALUATION CRITERIA

\begin{tabular}{|l|}
\hline \multicolumn{1}{|c|}{ CRITERIA } \\
\hline PROFITABILITY \\
COMPATIBILITY \\
TECHNOLOGY SUPERIORITY \\
MARKET GROWTH \\
MARKET SHARE \\
COST OF DEVELOPMENT \\
DIVERSIFICATION
\end{tabular}


Technology Development Evaluation Process ...

Most real world commercialization decisions, however, are more complex. As shown in Exhibit I-3, the primary fuel cell technologies are at different stages of development.

EXHIBIT I-3

FUEL CELL DEVELOPMENT TIME LINE

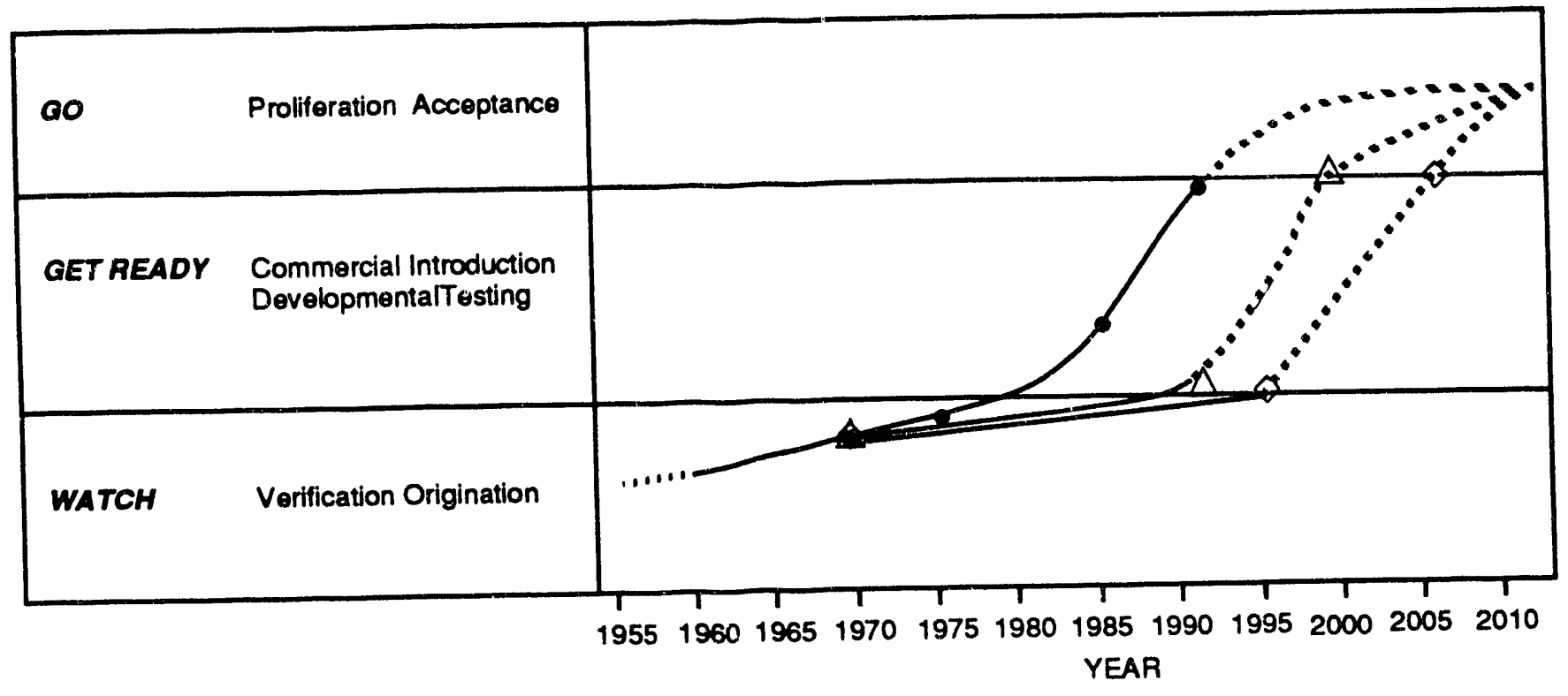

- PAFC $\triangle$ MCFC $\bigcirc$ SOFC

Further, these technologies compete for different market segments.

- Small sized phosphoric acid fuel cell systems have passed the commercialization hurdle, and plant investment has been made. The $200 \mathrm{kw}$ product is aimed at on-site applications, and may well have a market position relatively unaffected by the future introduction of molten carbonate technology.

- Utility sized phosphoric acid fuel cells have been demonstrated, but a commercial scale production facility has not been established. This technology is further along the product development path than molten carbonate technology, but is competing for the same market. Considering that the molten carbonate technology appears to have the potential for lower cost and higher efficiency once it is developed, the phosphoric acid commercialization investment question is difficult. If utility sized phosphoric acid systems have only a limited market opportunity period before molten carbonate systems dominate, then the investment must pay off quickly. 
Technology Development Evaluation Process ...

- Solid oxide fuel cells are at an early stage of development by comparison to the other two technologies. They show, however, potential for good efficiency, fuel flexibility, and long life. When they are finally poised for commercialization, they will likely have to penetrate a market served by mature competitive technologies. They will, therefore, have to offer the user larger advantages than if they were competing at a similar stage of development today.

- Competing molten carbonate fuel cell ventures are the clearest case of parallel developments which can be compared directly. They are at similar stages of development and are targeted at the same utility, large on-site, and industrial co-generation markets.

The options available are broad, and the fuel cell community (fuel cell technology development sponsors, developers, and end-users) requires an approach for evaluating each technology for commercialization. Further, reliable and comparable cost estimates are needed for sponsors and developers to make sound decisions in this environment. It is particularly important that projections made early in the development cycle be essentially the same basis as estimates made at commercialization. This is important in order to measure the progress of a given technology and to make more meaningful comparison of competing technologies which may be at different stages of development.

Numerous methodologies exist for evaluating technologies for commercialization. One business analysis approach that combines micro-economic, engineering, and financial analyses in a way that allows rational comparison of technology options is described below.

\section{BUSINESS ANALYSIS APPRO :CH}

When evaluating technologies for commercialization, one must simultaneously compare both the technical and economic advantages/disadvantages of each techrology option. Booz.Allen \& Hamilton Inc. and Michael A. Cobb \& Co. were requested by DoE METC to develop a structured approach that sponsors of technology development could use to evaluate a technology design option, ard assess the probability of successful commercialization.

We developed a generic approach to evaluate technologies competing for commercialization funding to determine those which present the highest economic value with the least technical risk. This approach assumes that a technology which offers the greatest value at an acceptable level of risk to both the customer (e.g., electrical utility company) and to the producer (e.g., fuel cell manufacturer) of the technology will have the highest probability of being successfully commercialized. Such a technology will be "pulled" by the market place due to the value that it creates for the customer and be "pushed" by the developer (manufacturer) because of the technology's potential profitability. 
EXHIBIT I-4

BUSINESS ANALYSIS APPROACH

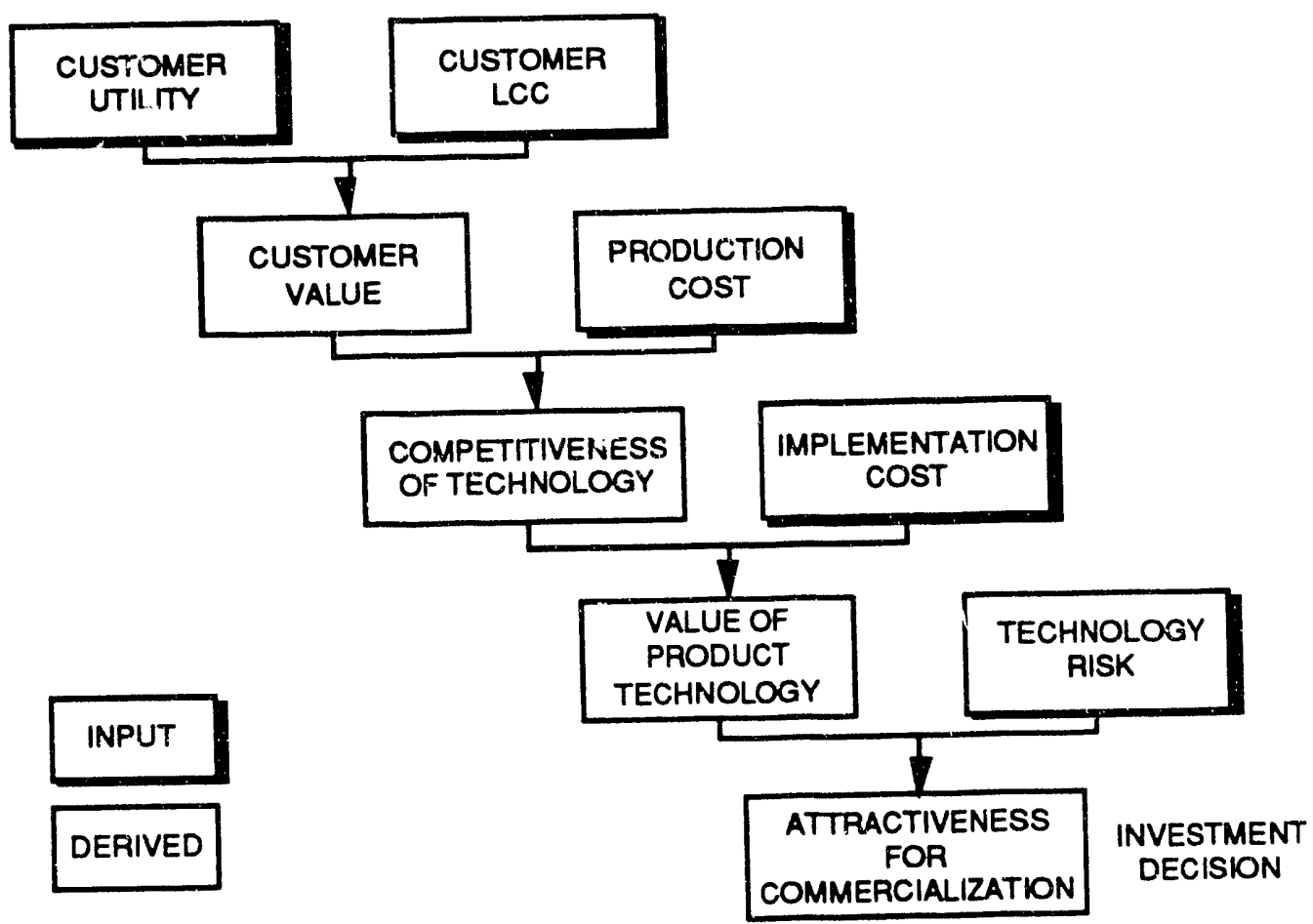

The approach, as shown in Exhibit $\mathrm{I}-4$, is based on the following four basic economic and technical premises:

1. That the value of a product to a customer is a function of the differential between the performance delivered by the product and the costs of owning and operating the product, with both performance and cost defined in the broadest sense

2. That the competitive advantage of a product to its producers is measured by its ability to increase the spread between a product's customer value and its cost of production

3. That the economic value of a technology development is determined by the amount the competitive advantage gained exceeds the investment required to implement the program when both are reduced to present value

4. That the attractiveness of developing a technology into a commercial product is a function of the economic value created, balanced against the inherent technical and business risks involved. 
Technology Development Evaluation Process ...

While the measurements incorporated in this approach are being used in many organizations, they are typically determined and evaluated in isolation. The value of this approach is the simultaneous consideration of all measiurements in a rational, structured manner. This approach is generic in nature and can be applied to any technology area. Howev?r, in the overview presented below, examples of how it can be used by the fuel cell community are described.

This approach is designed to evaluate a group of technology/design alternatives on a relative basis. For example, when comparing competing fuel cell designs and technologies for a given application, the change in customer utility and life cycle costs are measured against an established baseline electrical power plant to determine the change in customer value when different fuel cell designs are incorporated into the power plant. The reason for measuring the relative differences, as opposed to the absolute values, is due to the fact that it is difficult to separate the value created solely by the fuel cell from the value created by the entire electrical power plant.

Prior to conducting the analyses of this approach, it is imperative to establish a baseline scenario in order to derive consistent and comparable results. The baseline scenario must be adequately defined to minimize variations in the estimates due to differing interpretations, yet allow adequate flexibility to capture the subtle advantages of each technology option. When developing the scenario, input and consensus should be obtained from the groups responsible for providing data to, and conducting, the analyses. As a minimum, two areas should be well defined for the baseline scenario before beginning the analyses.

- Application - defines functional requirements, customer requirements, performance goals and operational parameters. To evaluate fuel cell alternatives, one should establish an electrical power plant design that may specify power and loading requirements, site location, operating requirements, raw fuel, non-variable equipment (i.e., equipment which would not change as different fuel cells are integrated into the plant), expected useful life, and maintenance and operations plan.

- Production Scenario - provides guidelines to which the production cost estimates must conform. As mentioned earlier, previous audit experience indicates that production cost estimating approaches can vary significantly and thus are difficult to compare. The production scenario may include the production rates, anticipated learning curves, cost of capital, use of new/existing facilities, labor rates, and taxes.

In addition, a common cost estimating denominator must be identified and applied consistently throughout the analysis. The denominator ensures that the results developed during each step of the approach can be compared and combined. In the case of fuel cell technologies, the denominator may be the cost per power plant, where a single plant may, for example, have ten fuel cells. 
Further, if during the analysis it is necessary to deviate from the baseline scenario, the reason for doing so should be documented in order to be accounted for at least qualitatively.

Each element of the business analysis approach shown in Exhibit I-4 is quantifiable and is used the subsequent analysis. Each element of the approach is described below in the same sequence as the overall business analysis would be conducted. Illustrations of how the required analysis for each element could be performed when evaluating fuel cell alternatives are also provided where applicable.

- Customer utility - is the measure of gross revenues generated by the technology for the customer over the life of the product. In the case of an electrical utility customer, this would be the price at which the electricity generated by the fuel cell plant could be sold for plus the value of any residual energy produced in the power generation process which could be used for heating, steam generation or sorption cooling applications. In addition, the low emission levels of fuel cells may have economic as well as social value in situations where low pollutant "credits" have a market value. Approach 63 for determining customer utility have been developed by the fuel cell and electric utility community and are well understood. For this methodology, customer value shou!d be assessed in terms of present value.

- Customer life cycle cost (LCC) - is the total cost of ownership and operation a customer will bear to realize the technology's utility. As with customer utility, numerous models exist to determine LCC for fuel cell power plants, and these models are also well understood. Typically, these models capture the costs associated with:

- Plant equipment and installation

- Fuel (operating efficiency)

- Maintenance and operation

- Financing.

Other costs which should also be incorporated into the LCC estimate include scrap and disposal credits, losses due to service down time, and CSA replacement/integration costs. For a given period of time, the customer LCC estimate, developed in present value, is subtracted from the estimate for customer utility to determine the value of the technology to the customer. 
- Customer value - is the difference between tie customer utility and customer life cycle cost in present value. The resulting value is indicative of the price the customer is willing to pay to obtain a particular product or technology. For industrial goods such as fuel cells, a. product technology presents a value to a customer only if the generated revenues exceed the total cost of ownership and operation. As the spread between revenues and LCC increases, the value of the product technology to the customer increases. For example, a fuel cell with a higher operating efficiency would have greater customer value assuming the fuel cell acquisition costs does not increase significantly.

- Production cost - is the estimate of the total production cost of a product technology based on the pre-defined production scenario. Production costs can be segmented either by three manufacturing cost elements (material, labor and overhead) or by major product component (including assembly and test). When developing production cost estimates for competing technologies it is imperative to establish clear rules and guidelines for estimating critical cost elements such as overhead, deprecation, and scrap and waste. In previous manufacturing cost audits, these elements have been determined differen:tly by various fuel cell manufacturing companies. As such, the results of the production cost estimates were difficult to compare. In Chapter II of this report, we provide a structured approach for determine detailed production cost estimates.

- Competitiv eness of technology - is the difference between the production cost and the customer value. This measure is estimated from the technology developer's perspective, and is of keen interest because it is indicative of the potential gross profit margin the technology may yield. The greater the potential profitability of a technology, the greater the likelihood that it will generate adequate revenues for the technology producer to offset the commercialization costs necessary to implement the program.

- Commercialization cost - is the estimate of the total cost required to establish the necessary infrastructure to produce and deliver the newly commercialized product. This includes all non-recurring costs associated with manufacturing technology development and implementation, product design improvement for commercialization, establishment of supplier/ subcontractor relationships, and other activities necessary to commercialize the product. Commercialization cost does not include items included in the production cost overhead such as capital depreciation and cost of financing. The baseline scenario established initially will dictate what elements will be included in the implementation cost estimates. 
While estimating the commercialization cost, critical issues that may impede the commercialization effort should be identified and reflected in the risk assessment element of this approach. Examples of such impediments may include inadequate production processes, limited material availability, or limited supplier production capacity or capability. In the case of fuel cell technology, the initial uncertain availability of wide nickel clad stainless steel was considered to be a potential impediment to the full scale commercialization of molten carborate fuel cells.

- Value of technology - is the difference between the technology's competitiveness (measure of gross profit margin) and the commercialization cost yielding the net profit potential of the technology. Based on this approach, the greater the value (hence, profit potential) of a technology, the greater the interest the developing firm's top management will have in committing resources to the commercialization of the technology.

- Risk assessment - is a quantitative value which must be determined to reflect the uncertainties associated with the development and production of a technology. The resulting risk assessment value is then used to determine the extent production and commercialization costs may increase as a result of the uncertainties being unfavorably resolved. When evaluating competing technologies for commercialization, a standardized approach should be developed and consistent used for each risk assessment. A variety of quantitative modis exist to evaluate risks of technology and its impact on production and implementation cost estimates.

- Attractiveness for commercialization - is the range of potential value of the technology to the developers when risk of commercialization uncertainties are taken into account. It is not uncommon that when the full risk potential of a technology is understood, the value of the technology to the producer is negated. At this point, however, the decision to proceed with the technology commercialization plan becomes strategic. This final measure is important to sponsors of technology development because the lower the risk of a technology, the greater the probability of commercializing the technology cost effectively and expediently.

\section{SUMMARY}

This approach demonstrates one possible way to evaluate technologies by considering several measures both from the customer's and developer's perspectives, using a common cost estimating denominator. The underlying philosophy of this approach is the simultaneous comparison of micro-economic, technical, and financial measures to determine the 
Technology Development Evaluation Process ...

ultimate value of a technology. Conducting the analyses contained in the above elements in isolation may lead to a commitment of scarce time and resources to a technology which is commercially unviable.

Beyond a quantitative business analysis, other issues must be addressed when making commercialization decisions. Such issues may include the assessment of technologies which can directly or indirectly supplant the technology under consideration, timing of market requirements, extent and availability of material, and the capability of the supplier infrastructure.

This chapter presented an overview of the technology commercialization process, pertinent issues, and one approach for conducting business analyses during the commercialization process. A key element of the business analysis approach is the estimate of the production cost, since it must be reliably estimated in a consistent manner. Difficulties frequently arise when attempting to compare production cost estimates developed by different organizations. Chap:-s II offers a structured approach that can be used to forecast the probable product cost of new products. 
II. A PRODUCT COST ESTIMATING APPROACH 
This chapter describes an approach that can be used to forecast the probable production cost of new products and demonstrates this approach using a hypothetical example based on the production of fuel cell separator plates. One useful application of this technique would be to help agencies sponsoring research and development activities to better assess and prioritize technologies competing for funding. The framework to be presented is intended as a guide to the development of such production cost estimates, with the particular objective of making the estimates comparable between multiple developers.

This approach assesses product costs at a given level of "steady state" production. It has been used for estimating fuel cell stack production costs assuming successful development at some future time. Its primary use is for determining if a technology can meet targeted market entry prices, and for identifying manufacturing or product technology barriers to commercialization. Identification and assessment of the impact of such barriers on product commercialization is of key interest to agencies considering the allocation of scarce funding dollars.

\section{ESTIMATING PRODUCTION COST}

The estimating approach described in this chapter can be used to assess production costs for one product or to make comparative analyses of competing products. The approach to be described assumes the viewpoint of a sponsor wishing to make a comparative analysis of competing technologies. It can easily be adapted to single product costing studies. This technique is most applicable at the advanced development and testing phase of the product commercialization framework shown in the previous chapter. Using the same basic methodology at earlier stages of the product development cycle will make subsequent updates and revisions easier than starting anew. The level of detail in the supporting data and analyses at earlier stages is necessarily lower.

A manufacturing plan and product design forms the baseline from which the production cost will be determined and manufacturing process technology risks will be assessed. It is part of the estimating team's responsibility to assure themselves that the production cost estimate is based on the best projected design and manufacturing processes that have a commercially established or laboratory proven basis at the time of the estimate. This precaution mitigates the effect of uncertainties in yet unproven design and process proposals.

The cost estimating process provides an opportunity for the estimating team to review and critique the design from a manufacturing cost and feasibility view point. This can provide the design and manufacturing teams valuable insight into the design and process elements that are difficult or costly to make, and lead to useful improvements. Evaluation of fundamental performance issues such as power density and product life which impact on costs are typically beyond the scope of a cost estimate. These values are taken as given. 
A Product Cost Estimating Approach ...

Initial familiarization - is to develop an understanding of the configuration and performance specifications of the products to be studied. It is imporiant to ensure that each configuration being estimated is equivalent in function or to understand clearly the differences. For fuel cell stacks, these differences might be expressed in terms of:

- DC power output

- Expected stack life

- Fuel type

- Extraordinary shipping expenses

- Field erection and start-up costs

- System coc. boundaries involving power plant subsystems such as power conversic ., fuel reforming, waste heat recovery, air pumping, and system enclosures

Other parameters of interest include:

- Power density -- watts per square foot of active area

- Active cell area

- DC power output per cell stack module

- Internal or external reforming

- Pressurized or non-pressurized operation

These areas are "designer's choice" and, in general, are accepted as given. Extreme differences in parameters such as power density should be probed to ensure that they are technically supportable.

If two or more technologies are competing for funding, the objective in this step is to understand the fundamental differences in design that impact the production cost. If possible at the outset, the sponsor should "level the playing field" by specifying a common design basis to be used for comparison. If this is done at the outset, comparisons can be expressed in terms of dollars per kilowatt of output, dollars per square foot of active cell area, dollars per pound of material, and the like. Slight differences in product configuration will be adequately "filtered" using such comparison factors. At the least, differences in design must be clearly understood to make meaningful comparisons between two dissimilar or competing technologies. 
A Product Cost Estimating Approach ...

Beyond the baseline design and performance factors already mentioned, a core collection of baseline data is necessary to begin the estimating task.

- Characterization of unusual design attributes unique to the product's components or subassemblies

- A bill of materials for major components driven from the product design

- Factory conceptual designs including equipment descriptions and any unique specifications

- Process planning data used in estimating costs of major operations

- Cost tracking data (labor hours and process rates) for similar or comparable products or processes to substantiate the basis for a yet to be developed process line (should also include scrap and waste data)

- Vendor cost data and quotations for same or similar materials and component parts

The outcome of a review of this data is the familiarization with the developer's factory conceptual design, cost estimating approach, and related data. This basic understanding will enable the cost estimating team to conduct a detailed review.

Detailed review - is initiated to assess the manufacturing technologies required to produce the product used as the basis for the estimate. These include some or all the following:

- $\quad$ Studying the existing prototypes and projected production designs in detail to develop design understanding

- Identifying critical design parameters and areas that are over-designed or susceptible to simplification

- Reviewing drawings, sketches, and process sheets in combination with design documentation and the bill-of-material to decide the basis for cost estimates

- Discussing make-or-buy options with the developer to assess the reasonableness of their conclusions

- Identifying key process options, and reviewing tradeoff analyses completed by the developer in arriving at the recommended concepts 
A Product Cost Estimating Approach ...

- Reviewing capital costs and labor manning estimates

- Reviewing the application of learning curves to the various processes where used

The likely outcome of this will be the identification of several issue areas requiring more focused analysis. The types of investigations and analyses involved might include some or all of the following:

- Reviewing bills-of-materials to assess their completeness

- Analyzing key components to determine their producibility in a high volume commercial plant

- Assessing the labor hours associated with various flow line processes and discrete manufacturing steps through direct observation or review of production logs or other data

- Reviewing yield and scrap assumptions at all process steps

- Auditing material cost estimates and soliciting vendor input for selected critical components where necessary. Critical components would be those judged as non-commodity in nature or those determined to be generally not available in current markets because of technological or supply side constraints

- Reviewing the fundamental financial assumptions for labor rates, utilities, capital costs, inflation factors, and the like

- Reviewing major capital equipment requirements and costs

- Reviewing manufacturing concepts and conceptual plant layouts

- Using published values of multipliers to account for inflation of building and equipment costs

- Applying reasonable scaling factors to correct for scale or size changes in cell stack design from prototype to full-scale production models

- Analyzing learning curves to identify those more appropriate to the various manufacturing techniques planned for use 
A Product Cost Estimating Approach ...

Cost segmentation - is used to identify high cost components, processes, or other cost elements for further examination of estimating approaches and possible cost reduction. The main objectives of a production cost estimate from a sponsor's point-of-view should be to:

- Assess the degree to which the projected manufacturing and product technology is, or was, corroborated

- Determine the plausibility of projected product design or manufacturing technology developments

- Assess the risk of cost increases over projections

- Find opportunities for process and design cost improvements

- Identify development needs

Cost Segmentation is an effective tool for making these assessments.

Cost segmentation first develops a cost derivation from the bill-of-materials, using a "bottom-up" approach. Having completed this analysis, the costs can be grouped into various categories, or cost segments, to aid in the identification of "cost drivers". Cost drivers are those factors that impact the production cost in the greatest manner (e.g., material, labor, unique processes, specific product components).

A segmentation methodology found useful for analyzing fuel cell stack production costs uses two categories:

- By major manufacturing cost element - material, labor, and overhead categories.

- By major cell stack assembly component

The segmentation can be tailored in detail to the application. Generally, the amount of data available from the above segmentation approach will provide adequate insights and sufficient detail to identify more areas in which focused analyses or cost reduction efforts are required. This is illustrated by a typical molten carbonate fuel cell stack's cost breakdown.

Exhibit II-1 shows that labor and other cost factors are but a small percentage of the total cell stack's cost. From a manufacturing cost view point, material cost is, by far, the largest cost driver. 
A Product Cost Estimating Approach ...

EXHIBIT II-1

COST SEGMENTATION BY MAJOR MANUFACTURING COST ELEMENT

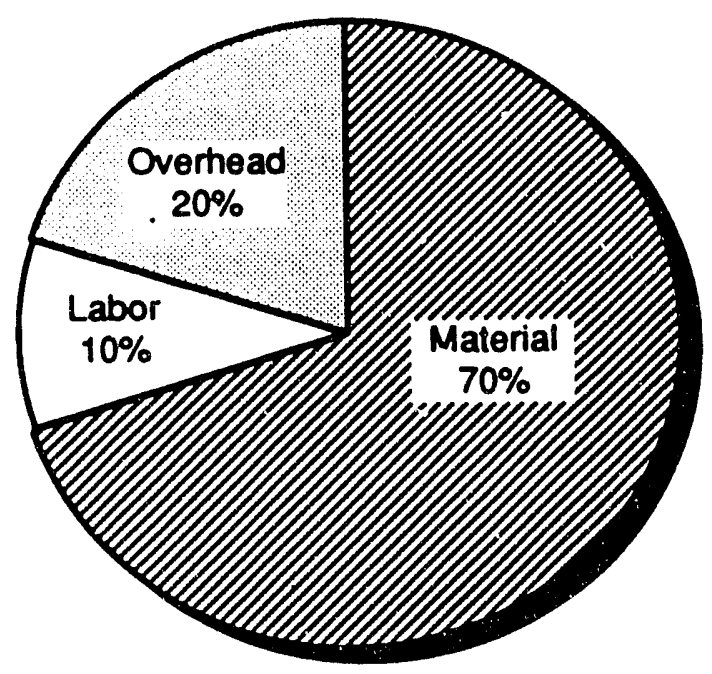

Exhibit II-2 reveals that the cell separator plate is a major cost driver from a component view point. More detailed analysis of the manufacturing cost elements for this one component revealed that material is the largest factor of this component's cost. Detailed investigation and review of design and processing factors revealed that proposed metal coatings were high cost, and were a supply problem.

EXHIBIT DI-2

COST SEGMENTATION BY MAJOR CELL STACK COMPONENT

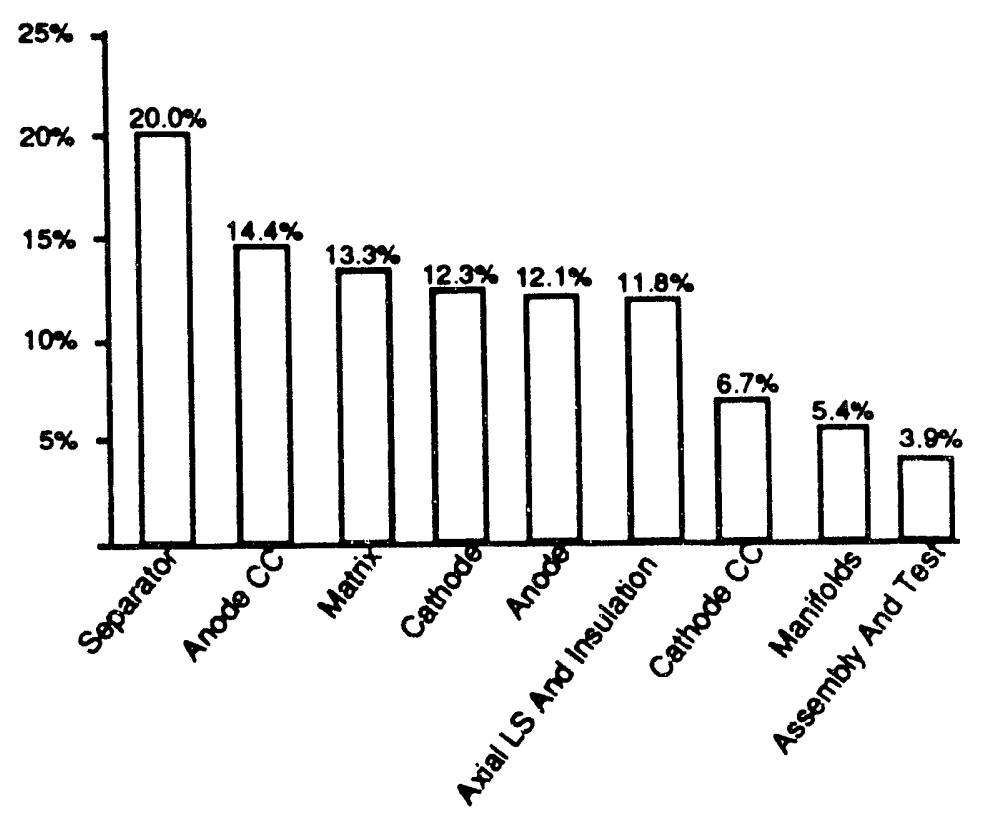


At this stage of the analysis, the understanding developed in the familiarization and detailed review stages is very important. Given a thorough understanding of the product design and manufacturing approaches, and an expert understanding of the manufacturing and technical issues, the analyses can be focused on critical cost areas. The outcome should lead to a thorough understanding of the manufacturing technology risks and opportunities, which is the objective of such an effort.

For separator plates, this step led to the identification of a significant infrastructure issue surrounding the supplier base. The lack of adequately developed supplier sources for key components places desired cost goals in jeopardy. The issues surrounding this topic for separator plates are discussed in Chapter III.

Key elements of a production cost plan - there are three major cost elements that must be considered in a production cost plan:

- Materials, including purchased parts and services

- Labor

- Overhead

How these cost elements are compiled will depend upon the product's design, the general manufacturing strategy, and the general accounting techniques employed by the estimator.

Exhibit II-3 lists the minimum deliverables considered necessary to make a thorough assessment of cost before commercialization.

\section{EXHIBIT II-3 \\ MAJOR DELIVERABLES}

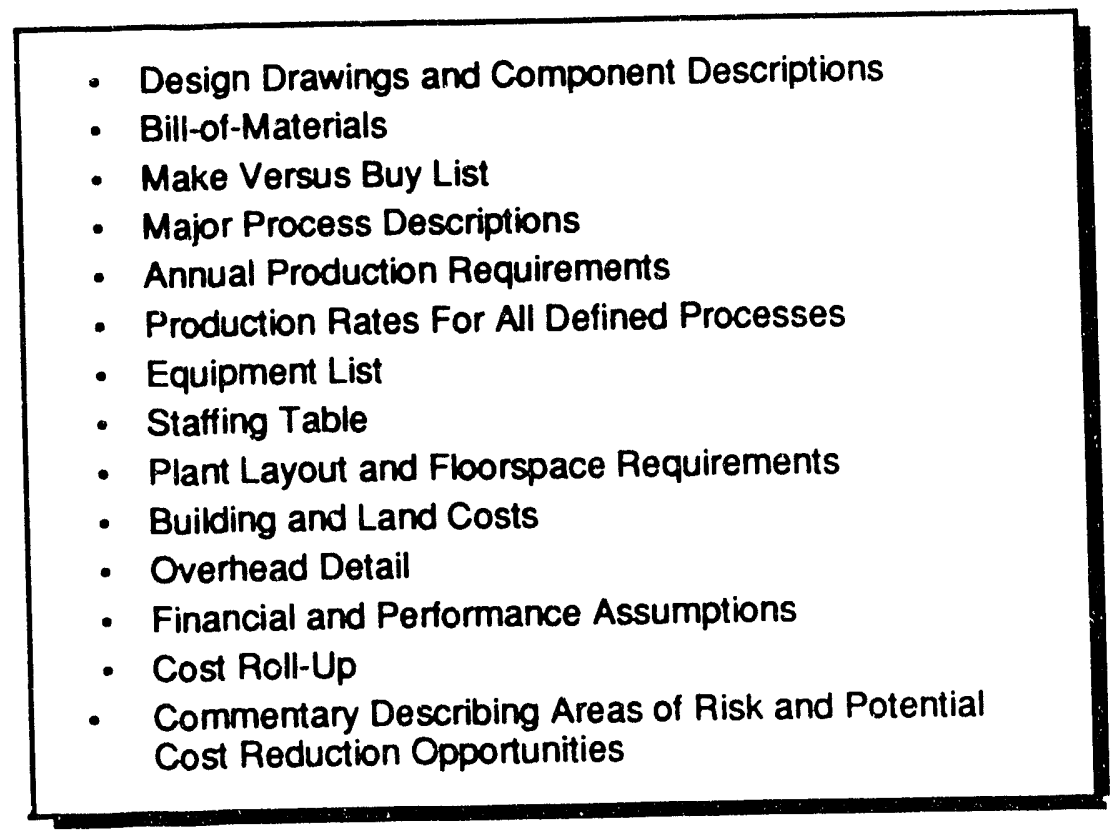


The following discussion describes the deliverables and underlying assumptions recommended for this level of production cost estimating. The comments are directed at a comparison of fuel cell stack production costs but could be used for any product.

- Design drawings and component descriptions - should be provided, with appropriate written or graphical descriptions of each item. Enough detail should be included to enable the estimating or review team to gain an understanding of dimensional characteristics and tolerances, function, and general position of the part or component in the assembled product. Descriptions of first or second level items on an indented bill-of-materials are generally sufficient.

- Bill-of-materials - describing all the raw materials and part quantities for one complete unit of product is a necessity and an indented bill-of-material (BOM) is highly desirable. The BOM will be used to determine the annual material and part fabrication requirements for various levels of production volume. Detail should be sufficient to enable the reviewer to find major subassemblies, individual parts comprising subassemblies, and the material cost per part.

- The BOM should include part or material quantities comprising each unit of production, material descriptio::5, dimensional information, and cost per part. It is very useful to have a supporting tabie showing the raw material characteristics in terms such as pounds per cubic inch or other appropriate units, and cost per unit of raw material. This data can than more easily be used in spreadsheet applications for cost calculations.

- Factors accounting for scrap and waste must be included in the production cost estimate, but are best inco morated in the estimates of annual parts production requirements is-e later discussion).

- Make versus buy list - is included in the BOM. This will enable the reviewer to identify those items planned for production in-house and to correlate the "make" list with the proposed manufacturing technologies. This correlation will ensure completeness of equipment, facility, and labor calculations in the cost model.

- Major process description - of the manufacturing technologies planned for use and descriptions of major processing lines or equipment items are necessary. These written descriptions should include sufficient detail for the reviewer to understand the proposed process, staffing requirements for operating the equipment, any uniqueness of the process or equipment, developmental requirements, and alternative processes considered if the technology is not commonly in use for similar components. These discussions also should identify any process services provided by outside vendors. 
A Product Cost Estimating Approach ...

- Annual production requirements - are listed in tabular form for all fabricated, purchased parts, and subassemblies. This should be computed using the BOM and annual volume requirements. The annual requirements must consider process scrap and waste losses in arriving at the amount of material or number of parts that must be started to result in the required number of acceptable parts. Scrap is defined as broken or defective parts and waste as trim or similar process losses. Recycle credit should be considered for high value materials such as nickel or noble metal catalysts.

- Scrap and waste vary from process to process, but if differences between processes are slight, an overall factor may be applied. An overall factor between $3 \%$ to $10 \%$ is not out of line at this level of estimating detail.

- In a comparative cost analysis, annual production volume must be specified as a constant for all parties to use. Alternatives may be computed to optimize the production capacity of expensive equipment to lower unit cost, but the baseline cost should use the same annual volume number specified by the sponsor.

Differences in cost with a fixed production volume will be attributable to differences in either design or manufacturing approaches taken. The annual production requirements will drive the development of the equipment list and staffing table.

- For fuel cell costing, production volume is generally expressed in megawatts of annual production and then converted to parts per year based on the output of the cell stack design being analyzed. A steady-state volume assumption is adequate at this level of business analysis. Later business and financial decisions will require more detailed cost assessments of production ramp-up over time.

- Production rates for all defined processes - are needed to determine equipment quantities and labor requirements. Production rates car be discussed in process descriptions (see preceding) or listed as a table entry in the equipment list (see following item). Production rates should be those expected at $100 \%$ operating efficiency less an appropriate factor for unscheduled equipment maintenance and downtime.

- Equipment list - summarizing each major item, quantity, new purchase cost, and installation / startup expenses should be provided in tabular form. This table may also include floor space requirements for facility planning purposes. 
- Staffing table - is prepared which shows the estimating or review team the planned labor compiement for a given volume of production. Production volumes expressed as annual requirements (see previous discussion) are necessary for this computation. Ideally, this table should be organized to follow the bill-of-material format, i.e., identifying parts with their respective labor requirements. This more easily allows the association of cost for both labor and equipment to individual parts or components.

- Salaried management and indirect hourly employees must be identified. Management structure should assume that the plant is a production cost center only. It should be considered an independent company, not receiving or purchasing services from a larger parent organization. Management should exclude marketing, sales, installation, field support functions, and the like. It should include general factory management, supervision, and technical suf rort functions, including human resources, payroll, and accounting functions.

- When possible, indirect hourly employees such as for support, material handling, maintenance functions, etc., should be assigned directly to the process line or manufacturing area they support. All other indirect hourly labor should be itemized by shift and function.

- Plant layout and floor space requirements - show the major process and equipment lines, and is necessary to assure that the capital or lease cost for building requirements has been adequately addressed as a cost item. This need not be detailed down to the "nth degree", but as a minimum should include labeled block diagrams on an overall drawing. Floorspace requirements for major equipment items can often be included for documentation purposes as line entries in the equipment list. Consideration should be given to include space allocations for equipment, work-in-process, major and minor traffic aisles, support equipment, supporting service departments such as quality assurance, maintenance, facility engineering, data processing, and other management support functions. 
- Building and land costs - add to the operating cost, and the capital requirements are significant. This can impact the allowance for "cost of capital" included in the estimate.

- Depending upon the manufacturing strategy, greater or lessor amounts of factory space will be required. Experience has shown many different approaches used in arriving at a factor for building and land costs in such estimates. It is best to arbitrarily assign a construction cost per square foot to floor space to minimize variations from differences in estimating approaches or geographic locations selected by the estimators.

- Building requirements should be determined for appropriate categories. Generally, factory, office, and warehouse categories are adeiquate, as most construction engineering data or architectural firms can verbally estimate these in "order of magnitude" numbers.

- Land requirements in acres should be determined based on factory requirements and cost per acre should be specified by the sponsor.

- Any building requirements attributable to unique process technologies, e.g., environmental controls, crane bays, etc., should be included with the capital cost of that item in the earlier equipment list and identified as such.

- Overhead - should include allowances in annual operating dollars for a variety of cost items such as depreciation, operating supplies, and sometimes indirect labor and management. Experience has shown this to be one area of extreme differences in estimating approaches that range from a "bottoms-up" buildup of costs, to a flat percentage applied to direct labor costs.

- If greater accuracy in absolute dollars is the goal, specify a "bottom up" approach using the list of items described in this section. This approach will only apply to an estimate which includes the total propused plant and all its processes and products. If absolute cost is not the driving concern, the same fixed factor applied to direct labor in all estimates is adequate to make a relative comparison of two or more competing technologies. A number between $100 \%$ and $150 \%$ (of direct labor costs only) would be appropriate. Application of an overhead factor as a percent of direct labor cost is appropriate when 
comparing two alternative processes where the balance-of-plant costs have not bcen determined. This factor allows for the costs of indirect labor and management not directly attributable to the process, as well as, the more typical overhead cost items such as utilities, operating supplies, depreciation, cost of capital.

- It should be noted that the overhead percentage just mentioned excludes payroll fringe benefits for vacation, holidays, employer's payroll taxes, and health and welfare plans. Such fringe factors are best added to the cost of payroll expenses when computing direct/indirect, salaried/hourly labor costs. A fringe benefit factor is suggested under financial assumptions below.

- A list of the most typical items included in overhead is shown below. This list is sufficient in detail for most cases where an itemized overhead accounting is determined necessary.

- Utilities

- Electric

- Water and sewer

- Heating gas or oil

- Trash and hazardous waste disposal

- Telephone and communications

-. Maintenance, repair, and operating supplies

- Taxes and insurance

- Real estate

- Personal property

- Cost of capital

Cost of capital is the financing expense required for the investment in facilities, equipment, and working capital. It should not be confused with capital costs (i.e., initial cost of equipment and the like). Dollars for the purchase or lease of equipment and facilities, and the payment of operating expenses will either be borrowed from financiers or paid by stockholders' equity. Such investments are not without cost and should be recognized in a production cost estimate when greater accuracy in absolute dollar cost of the product is the goal of a study.

Cost of capital can be a significant factor in a production cost estimate, and the differences in the way companies are financed may result in a competitive advantage or disadvantage. Standardizing an approach to estimating the cost of capital when evaluating technologies will eliminate 
the influence of business decisions yet give sponsors some insight into the potential market entry cost. All other things being equal, the cost of capital will vary for different scenarios depending upon a product's design and the manufacturing technology employed.

It is not always necessary to compute cost of capital unless greater accuracy in estimating the absolute dollar cost of a product is desired. Thoughtful comparison of the strengths of competing technologies can be obtained without using this factor.

A reasonable estimate of the cost of capital for this level of business analysis can be computed in the following manner:

- Assume an interest rate of prime plus two percent, and an inventory turn rate of 12 times each year (i.e., once per month). Turn rates will vary by industry and the ability of the manufacturer to function in a just-in-time mode. It may be more or may be less. For the purposes of estimating fuel cell cost, one inventory turn per month could be assumed.

- Compute the working capital portion by adding the annual costs of materials, wages, utilities and all maintenance, repair, and operating supplies. Divide by the number of inventory turns per year and multiply the result by the assumed interest rate.

- Compute the cost of capital on working equipment and facilities by adding the total estimated cost of all equipment, building construction, and land costs. Multiply the result by the assumed interest rate. The result is the cost of capital for equipment and facilities.

- Sum the two numbers to obtain the total estimated cost of capital for the proposed manufacturing scenario.

-. Depreciation

- Financial assumptions - must be defined for use by all developers if a comparison of competing technologies is to be made. The following factors are necessary:

- Definition of base year dollars. All costs must be expressed in the same base year dollars. 
- Hourly and salaried labor rates

- Two hourly categories - direct and indirect

- Three salaried categories - Management, professional, clerical

NOTE: Use of Bureau of Labor Statistics averages for geographic regions are often deceptively low are not considered appropriate for fuel cell start-up operations.

- Fringe benefit factor applied to payroll expenses to cover vacations, holidays, paid time off, employer payroll taxes, health and welfare plans. A factor of $40 \%$ is generally adequate. Some plans may be higher or lower.

- Personal, fatigue, and delay allowance of $15 \%(100 \%-15 \%=85 \%$ labor efficiency) applied to calculations when determining staffing headcount for direct labor.

- Depreciation should follow current tax laws. For most estimating purposes 31.5 years straight line depreciation for buildings and 10 years straight line for equipment will suffice. Land is not depreciated.

- Machine utilization or average machine "uptime" - is specified at a fixed factor between $85 \%$ to $100 \%$ availability. This will vary depending upon the equipment and company. "World class" manufacturing companies would approach the extreme high end of the range. A fixed rate is generally acceptable at this level of business analysis unless evidence from process descriptions suggests certain areas require different rates.

- Cost roll-up - is prepared in the form of a series of tables and charts using the preceding data and set of financial assumptions. It can be done manually or using a personal computer and one of the common business application spreadsheets such as Lotus 1-2-3 or Microsoft EXCEL. Spreadsheet models are preferred, as they generally can be easily modified to test alternative scenarios.

- Risk and cost reduction assessment - is prepared to capture the insights into cost risks and cost reduction opportunities that an experienced estimating team will typically develop during the course of the work. These should be included in the report and communicated to the development and manufacturing engineering teams. 
A Product Cost Estimating Approach ...

In the past, cost estimates conducted by developers at a sponsor's request have typically been reviewed by a third party audit team to check for accuracy, completeness, and reasonableness of the underlying assumptions. It has been useful in identifying and accounting for differences in design and process assumptions, and has also proven beneficial in identifying cost reduction approaches that might not have otherwise been considered. This practice could be particularly valuable in assuring a uniform estimating procedure for estimates prepared by competing developers.

\section{COST ESTIMATING APPROACH DEMONSTRATION}

The following pages and figures contain an example of the methodology by comparing two similar parts, but comprised of different materials. The comparison is based on a hypothetical separator plate, the base case is comprised of a stainless steel plate, nickel clad on one side; the alternate, a stainless steel plate, copper clad on one side. The facts and figures are typical of molten carbonate cell stack designs and industry material costs, but they do not reflect any particular developer's design, process, or costs. 
A Product Cost Estimating Approach ...

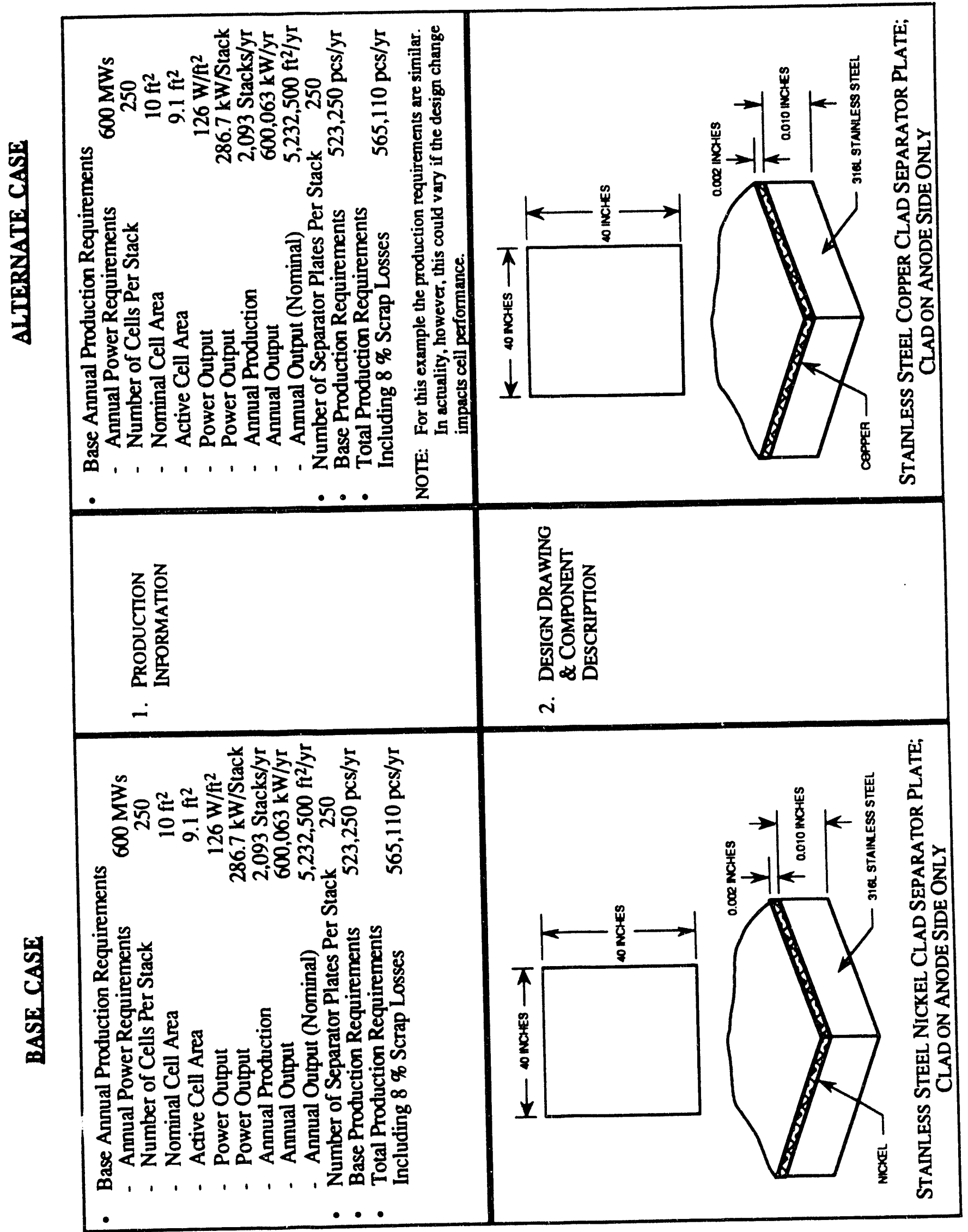


A Product Cost Estimating Approach ...

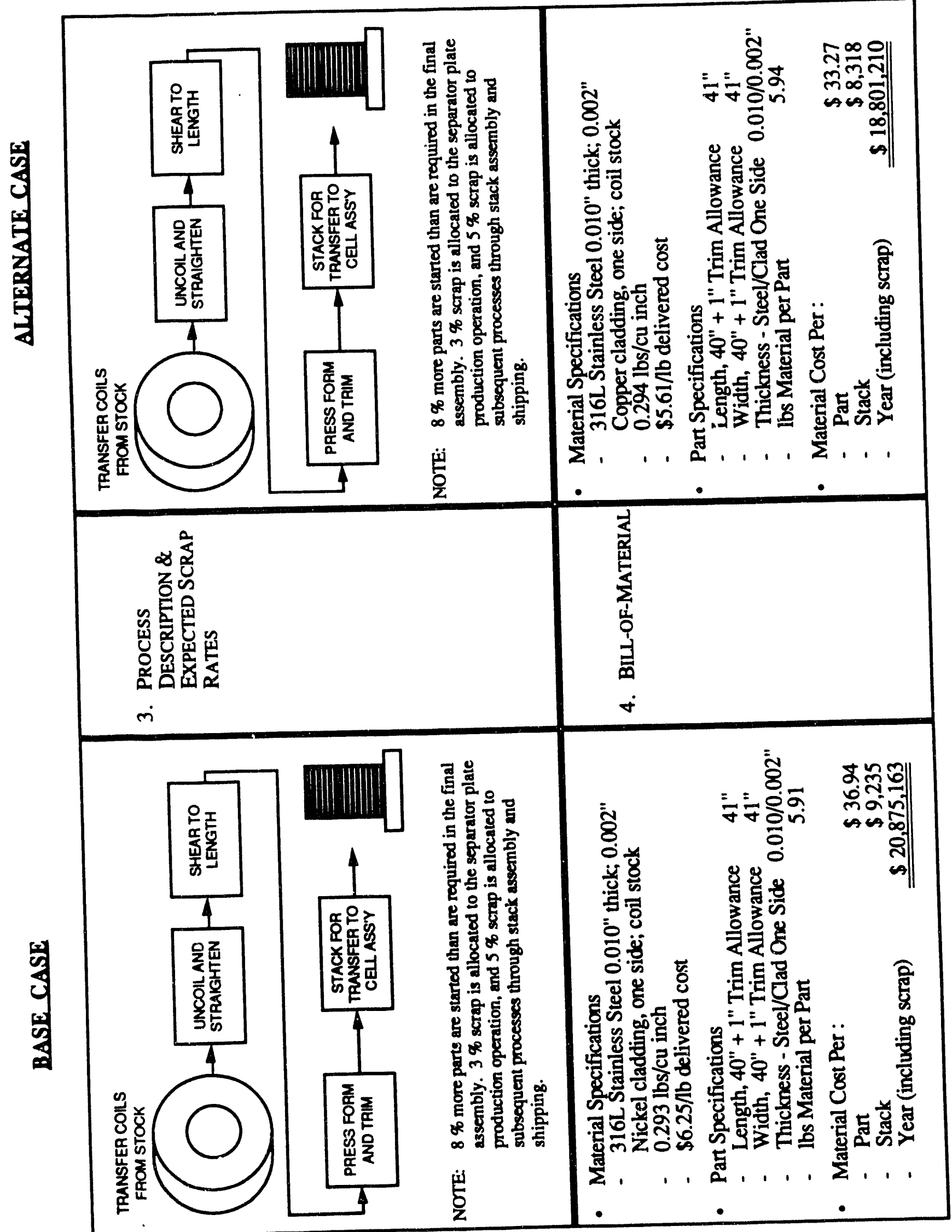

II -17 
A Product Cost Estimating Approach ...

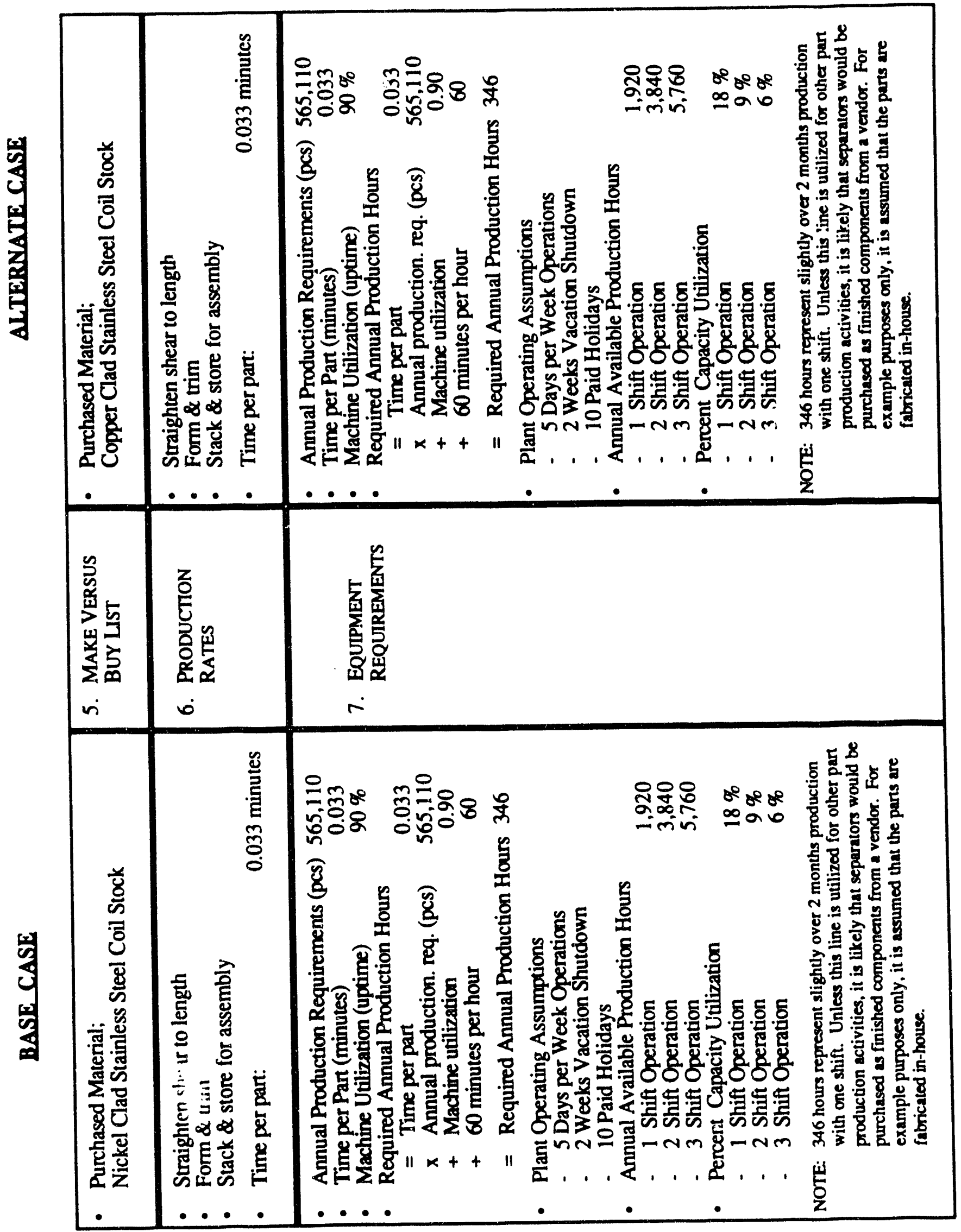

II -18 
A Product Cost Estimating Approach ...

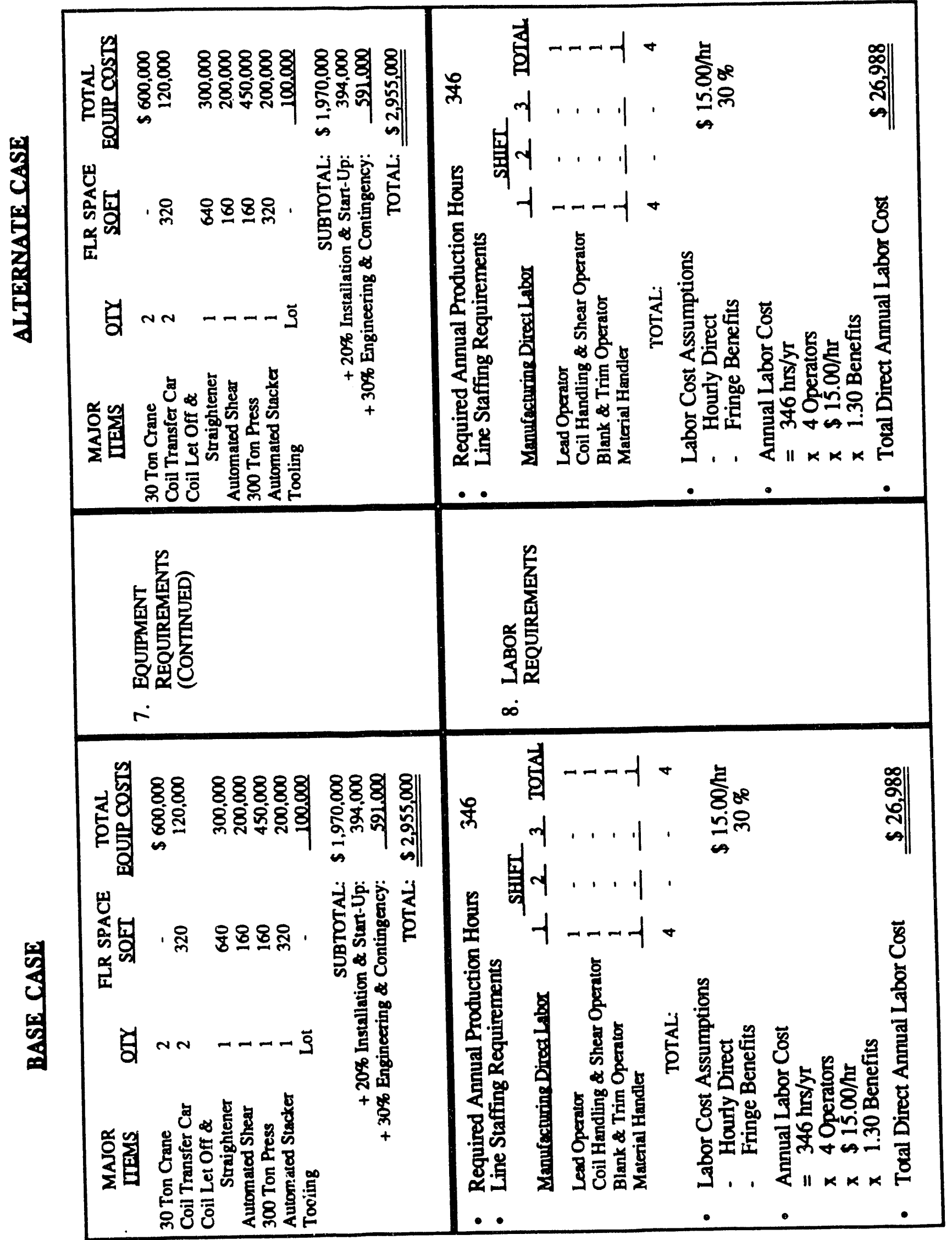

II -19 
A Product Cost Estimating Approach ...

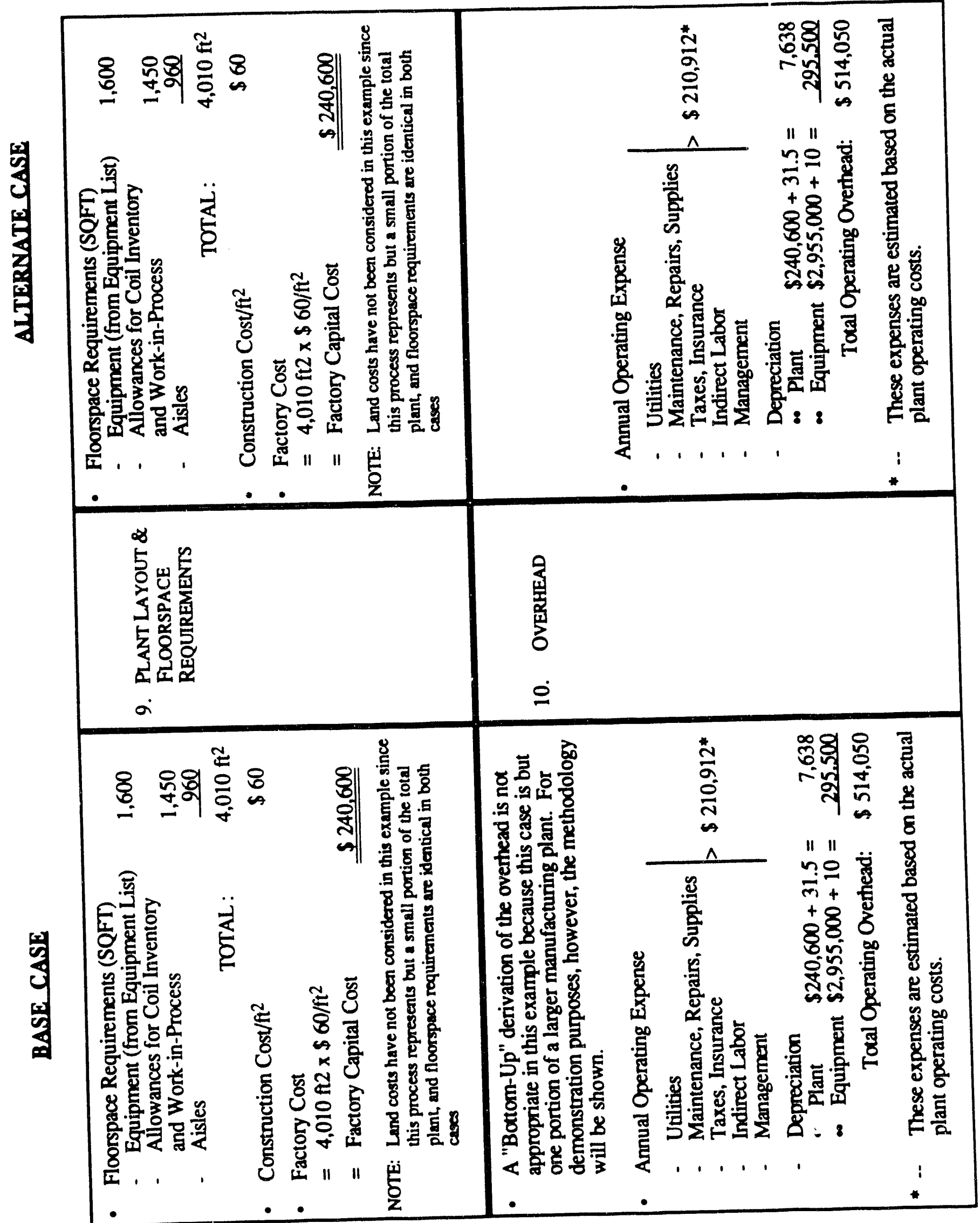

II -20 
A Product Cost Estimating Approach ...

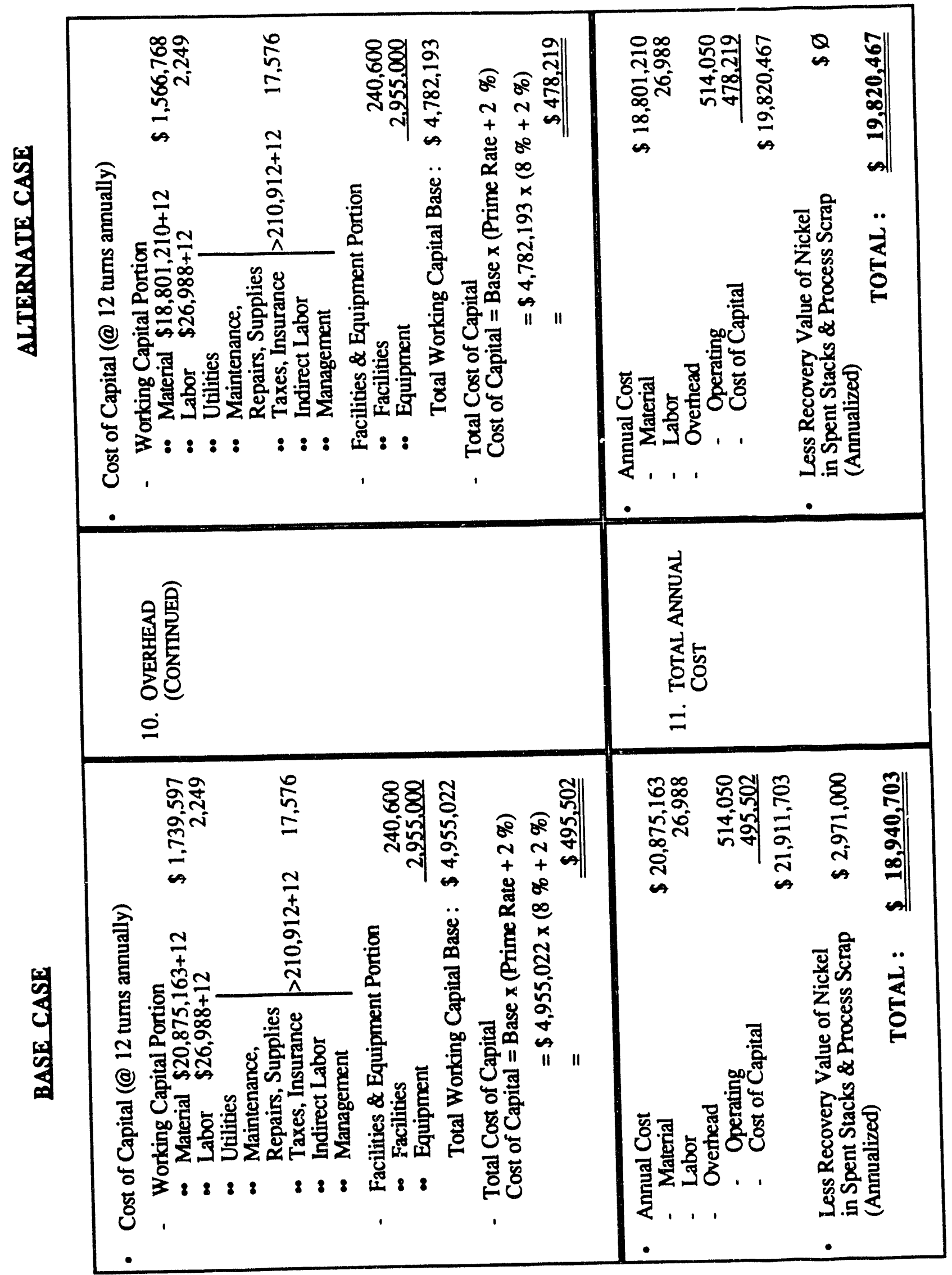

II -21 
A Product Cost Estimating Approach ...

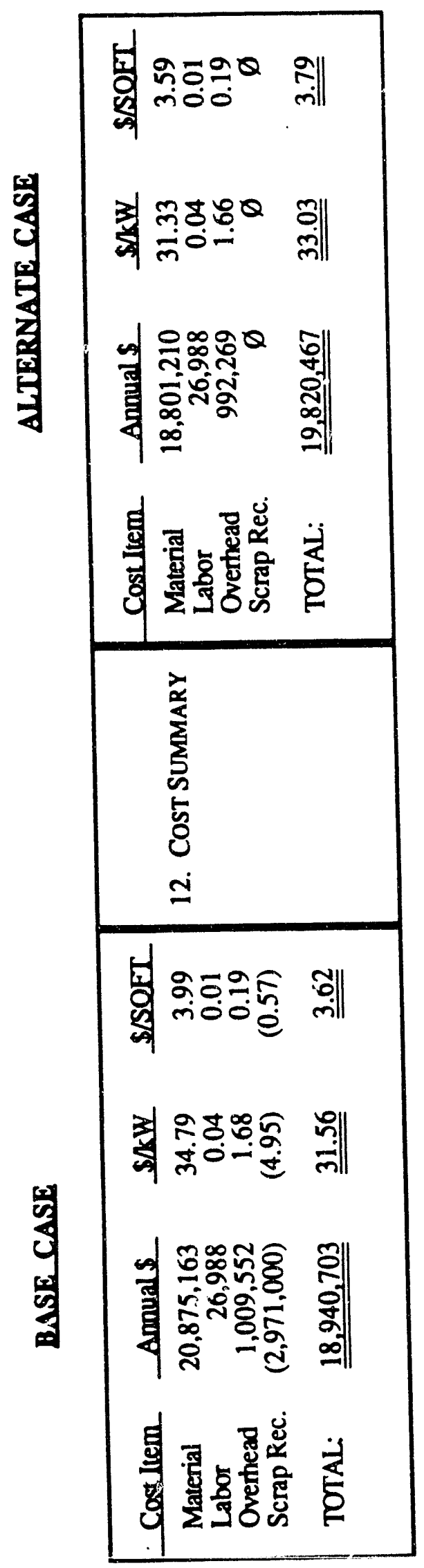


A Product Cost Estimating Approach ...

The example shows that the "bottom line" cost of the two separator plate alternatives is comparable when recovery value of the nickel is included in the cost. This example also demonstrates the need to look beyond individual part cost when evaluating alternatives. The primary use foreseen for spent cell stacks is as a source of nickel for stainless steel production. Other work indicates that "spent" stacks can have up to $\$ 40$ per $\mathrm{kW}$ of recoverable nickel material, primarily from the nickel content of the electrodes. Copper in any appreciable amount "poisons" the stainless steel melt and can destroy the nickel value of the stack.

\section{SUMMARY}

In this chapter, we have shown one recommended approach for estimating production costs of new products. Using this methodology, the material, labor, and overhead costs of production can be determined with reasonable accuracy. In addition, the data can highlight the cost of major product components in similar terms. Analyses of this data by experienced design and manufacturing engineers can lead to valuable insights into ways to reduce cost or to improve the product's design for lower cost or better manufacturability.

Experience in fuel cell cost analysis has shown that material cost dominates the cell stack production cost. For this reason, the estimating team may need to probe the availability and cost of critical materials. Case studies describing two such investigations are summarized in Chapter III. 
III. MATERIAL INFRASTRUCTURE CASE STUDIES 
Material Infrastructure Case Studies ...

Based on the commercial manufacturing plans and cost projections we have audited, the phosphoric acid and molten carbonate fuel cell developers generally plan to make key repeat components, such as the active elements, in house. These typically require specialized equipment and know-how which are proprietary to the vendors and are not available from suppliers. The developers will rely, however, on a variety of materials from outside suppliers. Some of these, such as phosphoric acid and carbonate salts, are commodity products which are not expected to present a supply infrastructure problem. Other materials, because of their size, specifications or quantity required, may currently have limited availability and require infrastructure development to support commercial production. We probed this area to develop a sense of whether there is, in fact, a problem and, if so, what might be done to help along necessary developments.

Case studies of carbon separator plates for phosphoric acid fuel cells and nickel clad stainless for molten carbonate fuel cells were carried out. These were selected because of their functional and cost importance, and because the audit experience indicated that the developers were relying on limited, often overseas, sources of supply. In both cases, domestic suppliers were identified who have interest and applicable facilities and technology but who are not currently involved in fuel cell commercialization. It is likely that the contacts established as a result of this study will bring some of these suppliers into the fuel cell commercialization programs. If this takes place, it may well improve material cost and availability to the developers and provide new business opportunities to the domestic suppliers.

\section{GRAPHITE SEPARATOR PLATE}

Thin, impermeable graphite or high temperature glassy, carbon separator plates are a key component in typical phosphoric fuel cell designs. They separate fuel and air, prevent acid migration between cells, carry the current generated, and withstand clamping and pressure stresses. The open literature indicates that resin-carbon composites or all carbon structures heat treated at low (approximately 900 degrees $\mathrm{C}$ ) temperatures have poor corrosion resistance, particularly at elevated operating pressures. Good corrosion resistance appears to require heat treatment at about 2700 degrees $C$. Large, thin ( 1 meter square by less than 1 millimeter thick) sheets with good flatness, low porosity, and the required heat treatment are not simple to make. This material is, therefore, not commonly available and is expensive.

The approach of this task was to identify potential suppliers of such material, and determine whether or not they are willing and able to become active suppliers to the phosphoric acid fuel cell industry. Contacts were identified through the Thomas Register and through Japanese business directories under carbon and graphite headings. U.S. contacts were made by telephone, letter, and visit, and letters were FAXed to the Japanese companies. 
There is at least one Japanese company with capacity to make these parts. This company currently supplies material for phosphoric acid fuel cells which appears to be made in a sheet forming process. The other Japanese graphite firms contacted did not respond to our letters.

Most U.S. graphite capacity is for electrodes and other products used by the steel and non-ferrous metal industries, and for military aerospace and chemical applications. Several of the producers make billets large enough that the plates could be sawed off and machined to size. Impermeability requirements might be met by impregnation and additional heat treatment. The labor required for the sawing and machining operations and the material waste involved appears to make this approach uneconomical compared to a sheet forming process such as the Japanese firm's.

Two U.S. producers appear to have. interesting processes licable to fuel cells:

- Company "A" has done development work on a calendering process which forms sheet directly. The sheets are heat treated and then graphitized in an induction furnace. The process was developed in a sponsored program for battery applications, but has not been commercialized. Company " $A$ " is currently well connected with the fuel cell community, and are up to date on the business opportunities.

- Company "B" has made phosphoric acid fuel cell separators in the past, but is not now involved in the business nor following it very closely. They have a patented continuous web process in which graphite fiber fabric is impregnated with graphitic pyrolytic carbon which is highly corrosion resistant. In the past they have been involved with fuel cell manufacturers, but they are not currently working on this process nor in the fuel cell area in general. Company "B" would seriously consider re-entering the business if there was a well established opportunity, and is interested in discussing the possibilities.

In summary, both companies appear to have interesting capabilities which could result in competitive domestic production of carbon plates. Company "A", with their current connections, seems to be positioned to move when the business situation is right. Company "B" should perhaps be encouraged to follow the situation more closely. 
Material Infrastructure Case Studies ...

\section{NICKEL CLAD STAINLESS STEEL}

Nickel clad 300 series stainless steel is a key material for molten carbonate fuel cells. The total material thickness requirement is 0.010 to 0.020 inches, of which about 0.002 is nickel. The key properties include nickel's resistance to anode corrosion, stainless's resistance to cathode corrosion, and hot strength. Plating and other nickel deposition processes have been proposed, but it is not clear that the adhesion, freedom from porosity, and ductility are adequate for this application. The clad material, which is formed by rollbonding the nickel and steel sheet together and reducing the composite to the final gage, has been used successfully in essentially all development cells.

The problem is that no U.S. mills currently offer clad material over 24 inches wide, and all the molten carbonate developers are now building larger cells. A current supplier of nickel clad stainless steel to the fuel cell industry makes a high grade of cold bonded clad material up to their mill width limit of 24 inches. A wider cold bond mill is possible, but is a major investment and has more capacity than the fuel cell market is likely to absorb.

In this case study we contacted domestic stainless steel mills to determine their interest and capability to produce wide clad material using existing capacity. Four companies responded favorably, although none now produce clad material in the thin gage required. We met with them for more detailed discussions of their technology, the product's requirements, and the projected size and timing of the fuel cell market. All are proposing some variation of a slab bonding and rolling process. This process has been in use for a number of years and is well proven. The requirement for thin gage is not usual, and is an area in which some process refinement may be required.

The projected annual MCFC clad material requirement is attractive to all four stainless producers. The fact that no major capital investment is required is a particularly positive factor. They plan to establish contacts and dialog with both METC and the MCFC developers to start to become part of the fuel cell community. In this way they can follow the market as it matures and update their plans appropriately.

Company " $C$ " is a leading manufacturer of nickel based alloy sheet, tube, bar, wire, and other shapes. They have 48 inch wide hot and cold rolling facilities capable of converting high alloy slabs into high quality 10 mil thick sheet in 10,000 to 20,000 pound coils. They seem fairly confident that they can supply material which will meet the technical requirements. Company " $\mathrm{C}$ " has not actually made such material, and would 
want to make trial runs to prove and refine the process. Their preference is to start with an explosively bonded slab. This bondi ; service is provided by one of their established suppliers. They would then treat thi: slab essentially the same as any other slab to be processed into thin, cold finished sheet.

Companv "D" produces a wide variety of carbon, stainless, electrical, alloy, and coated steels for the .utomotive industry, utility industry, and a variety of other markets. They feel that they can supply the grade of roll clad material required. They are also interested in seeing if electroplating, perhaps with some sort of subsequent heating and rolling process, could provide the coating integrity and ductility required.

Company " $\mathrm{E}$ " is a leading manufacturer of stainless steel plate and sheet, including clad products used for cookware. Company "F", also represented at the meeting, makes clad material, and is working with Company " $E$ " in pursuing the fuel cell opportunity. They work together as a regular matter, supplying each other with materials and services. The group is generally familiar with molten carbonate fuel cells and their specific material requirements. Company " $E$ " agrees with our findings that coatings such as electr! ating are unlikely to provide the quality of corrosion protection and ductility needed for this application. The feel roll clad material is the best solution, and that they can supply the required $0.010 \mathrm{t}, \quad 020$ thick sheet. They seem more comfortable with the thicker gage, and feel that it may $u$ more econom when the cost of rolling to thinner gage is considered.

Company "G" is one of the lurgest producers of stainless steel flat rolled sheets. They produce a full range of stainless alloys, including the 310 and 316 grades typically used in molten carbonate fuel cells. Company " $G$ " is owned by a French firm which is a major stainless steel reroller and produces clad material. Company " $G$ " has supplied clad cookware material consisting of carbon steel sandwiched between two layers of stainless. They can produce material down to 0.018 inches thick in 48 inches width, and down to 0.015 in 36 inches width in their own mills. They have relationships with rerollers who can further reduce the material to 0.010 thick in 42 inches width. Their immediate next step is to assess in more detail their capability to produce the material to the required specifications.

In summary, all four stair :ss steel producers appear capable of manufacturing this critical material in wide widths competitively with the overseas producer. Company "E" was already aware of the market opportunity, and others find the opportunity interesting and plan to explore it further. 
Material Infrastructure Case Studies ...

\section{SUMMARY}

These case studies suggest that potential domestic suppliers of materials critical to fuel cell production are not learning about, nor involved in, the opportunities early enough to participate the industry development. At best, they are in the discussion stages and lagging behind oversea suppliers in developing this market. In contrast, Japanese suppliers currently offer these materials in suitable sizes and specifications to both U.S. and foreign developers, and are seeing their materials built into key test and demonstration hardware. The domestic suppliers of these materials are therefore in a catch-up position in an industry and technology the U.S pioneered and still leads.

It is not clear whether these test cases are isolated incidents, or symptomatic of a general disconnect between emerging new industries and the established infrastructure which should, by rights, be supporting them. This question is important enough to both the established and emerging industries that it merits more study. It may be necessary to assist the free market forces so that buyers find sellers early in the game. 

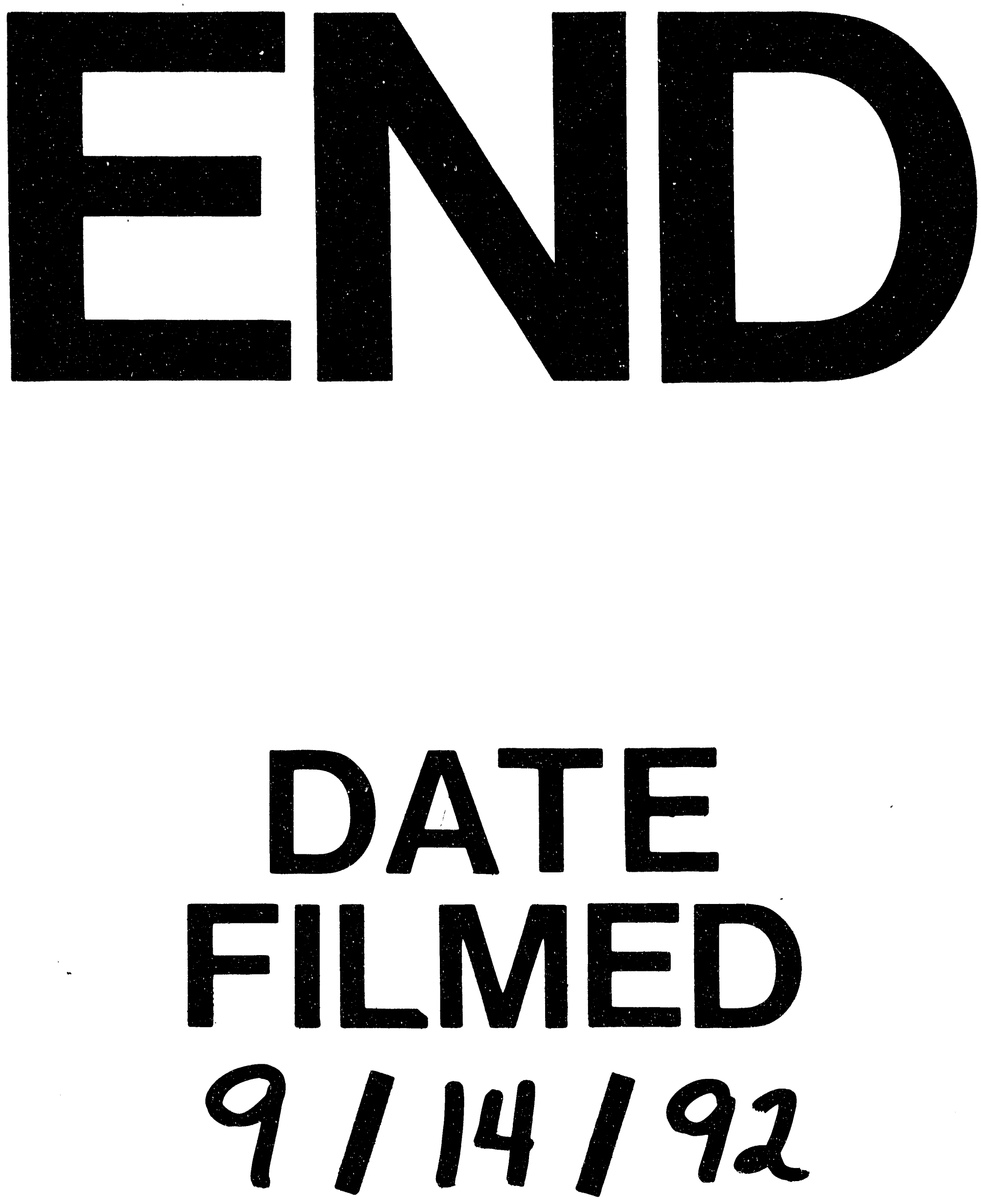
